\title{
LINEAR ORDERING OF CITIES IN THE SMART CITY CONCEPT
}

\author{
Adam SOJDA \\ Silesian University of Technology, Zabrze; adam.sojda@polsl.pl, ORCID: 0000-0002-3021-4451
}

Purpose: Linear ordering is an important issue for evaluating multi-attribute objects. The issue of assessing cities in the context of their rating in the light of the smart city concept is a linear programming issue. The primary purpose of the article is to report the results of linear ordering obtained based on different methods and to present comparative analyses.

Design/methodology/approach: The data presented in the article are based on EUROSTAT. It refers to indicators characterising selected European capitals.

Findings: Based on the indicators selected from the database, the ranking of cities is determined based on the presented methods. The results obtained were used for benchmarking.

Originality/value: The most significant value of the work is the benchmarking that was carried out. The analysis proved that the TOPSIS method showed that the result obtained was similar to that obtained by SCI.

Keywords: Smart City, Eurostat, Hellwig method, TOPSIS method, linear ordering.

Category of the paper: Research paper.

\section{Introduction}

The issue of the Smart City concept is particularly important when we consider the fact that in 2030 more than $60 \%$ of the population will live in cities (United Nations, 2014). It can be said that Earth will become an urban planet. Cities must be adequately prepared for such a huge number of inhabitants. The Smart City concept is convenient to meet this challenge. The concept evolves with increasing data processing capabilities and the availability of all technologies using AI. The perception of the challenges facing the city is also changing. The city is being changed like a kind of organism that is evolving. The evolution of the city is aimed at such a redesign of the city that serves its inhabitants. We are already talking about Smart City 5.0 (Svítek, 2020). 
Measurement and comparison are the goals all kinds of rankings should meet. Very often, the aspect of comparing obtained results is forgotten. Very often, the same result in the form of a ranking is presented. The ranking itself is not everything, it is important to delineate and indicate the ways of development. The Smart City concept has a hierarchical structure that is lost by imposing a concept of sustainability on it. The application of the concept of sustainable development results in the adoption of equal weights for each component. Many rankings are built, using different indicators. The data sources must be reliable (Ahvenniemi et al., 2017; Albino et al., 2015; Bosch et al., 2017a; Huovila et al., 2016; Stankovic et al., 2015; Lombardi, 2011; Tahir, 2016). Complexity means that there is no transparent assessment system. There are many concepts of a Smart City. The European Smart Cities Ranking uses six categories and 64 indicators, The Smart Cities Wheel considers six categories and 62 indicators, Bilbao Smart Cities Study uses six categories and 49 indicators. Smart City PROFILES consider just five categories and 21 indicators (Albino et al., 2015; Berrone et al., 2019; Bosch et al., 2017b.; Giffinger et al., 2007; Smart City PROFILES, 2013; Szczech-Pietkiewicz 2015; UCLG, 2012).

The categories, areas in which we perceive Smart Cities include: smart economy (ECO), intelligent population (PEO), smart management (GOV), intelligent mobility (MOB), intelligent environment (ENV), intelligent living conditions (LIV).

The construction of the Smart City rating is labour-intensive. It requires access to a database which often requires separate research. City rating is possible compared to other cities. Solutions should be sought to make the comparison possible without requiring additional financial resources, which can be achieved thanks to databases such as Eurostat. Eurostat is a reliable source of data. It has extensive databases of national and regional statistics. City related data are located in the Urban Audit database (Sojda et al., 2018).

\section{Data and Methods}

\subsection{Data}

Eurostat contains a database of cities. The data collected are from 1990 to 2019. The Urban Audit database contains 572 different indicators. Some indicators are objective. Subjective indicators are described on the Likert scale or by percentage share. The database contains 1,822 cities from 32 countries. Not all of them are described by the same number of indicators. The largest number of indicators is found for large cities and, above all, the capitals of countries. The study focused only on capitals that were selected using the data availability criterion. 
For data related to the perception of cities by their citizens expressed on the Likert scale, the following solution was adopted. Weights $(-2 ;-1 ; 0 ; 1 ; 2)$ are assigned to the response: (strongly disagree, very unsatisfied; somewhat disagree, unsatisfied; do not know/no answer, somewhat agree, rather satisfied; strongly agree, very satisfied). This allowed determining a synthetic answer to the question.

Variable values have been normalised (Kukuła, 1989, 2000; Sojda et al., 2020). The following tables list the indicators assigned to the relevant areas of the ranking.

Table 1.

Indicators in the ranking

\begin{tabular}{|c|c|c|c|}
\hline INDIC & NAME & MD & SD \\
\hline V01: ECO O1 & Activity rate & 1 & $\mathrm{~S}$ \\
\hline V02: ECO O2 & All companies & 2 & $\mathrm{~S}$ \\
\hline V03: ECO O3 & Unemployment rate & 0 & $\mathrm{D}$ \\
\hline V04: ECO S1 & In this city it is easy to find a good job & 0 & $\mathrm{~S}$ \\
\hline V05: ECO S2 & You have difficulty paying your bills at the end of the month & 0 & $\mathrm{D}$ \\
\hline V06: ENV O1 & Annual average concentration of $\mathrm{NO} 2\left(\mu \mathrm{g} / \mathrm{m}^{3}\right)$ & 0 & $\mathrm{D}$ \\
\hline V07: ENV O2 & Annual average concentration of PM10 $\left(\mu \mathrm{g} / \mathrm{m}^{3}\right)$ & 1 & $\mathrm{D}$ \\
\hline V08: ENV O3 & Number of days particulate matter PM10 concentrations exceed $50 \mu \mathrm{g} / \mathrm{m}^{3}$ & 0 & $\mathrm{D}$ \\
\hline V09: ENV S1 & The cleanliness in the city & 0 & $\mathrm{~S}$ \\
\hline V10: ENV S2 & $\begin{array}{l}\text { This city is committed to the fight against climate change (e.g.; reducing } \\
\text { energy consumption in housing or promoting alternatives to transport by car) }\end{array}$ & 0 & $\mathrm{~S}$ \\
\hline V11: PEO O1 & $\begin{array}{l}\text { Employment (jobs) in professional, scientific and technical activities; } \\
\text { administrative and support service activities (NACE Rev. 2, M and N) }\end{array}$ & 5 & S \\
\hline V12: PEO O2 & Median population age & 3 & $\mathrm{D}$ \\
\hline V13: PEO O3 & $\begin{array}{l}\text { Proportion of population aged 25-64 qualified at level } 5 \text { to } 8 \text { ISCED, from } \\
2014 \text { onwards }\end{array}$ & 2 & $\mathrm{~S}$ \\
\hline V14: PEO S1 & Foreigners who live in this city are well integrated & 0 & S \\
\hline V15: PEO S2 & Schools in the city & 0 & $\mathrm{~S}$ \\
\hline V16: LIV O1 & Infant mortality rate (per 1000 live births) & 0 & $\mathrm{D}$ \\
\hline V17: LIV O2 & $\begin{array}{l}\text { Number of deaths per year under } 65 \text { due to diseases of the circulatory or } \\
\text { respiratory systems }\end{array}$ & 2 & $\mathrm{D}$ \\
\hline V18: LIV O3 & Number of murders and violent deaths & 1 & $\mathrm{D}$ \\
\hline V19: LIV S1 & Health care services offered by doctors and hospitals in this city & 0 & $\mathrm{~S}$ \\
\hline V20: LIV S2 & You feel safe in this city & 0 & $\mathrm{~S}$ \\
\hline V21: MOB O1 & $\begin{array}{l}\text { Cost of a combined monthly ticket (all modes of public transport) for } 5-10 \mathrm{~km} \\
\text { in the central zone - EUR }\end{array}$ & 2 & $\mathrm{D}$ \\
\hline V22: MOB O2 & Number of registered cars per 1,000 inhabitants & 3 & $\mathrm{~S}$ \\
\hline V23: MOB O3 & Share of journeys to work by public transport (rail, metro, bus, tram) - $\%$ & 8 & $\mathrm{~S}$ \\
\hline V24: MOB S1 & $\begin{array}{l}\text { Means of transport primarily used to go to work/training place: public } \\
\text { transport }\end{array}$ & 0 & S \\
\hline V25: MOB S2 & Public transport in the city, for example, bus, tram or metro & 0 & $\mathrm{~S}$ \\
\hline
\end{tabular}

The factors were then transformed to match the desired higher values of the indicator. Most factors are de-stimulants (D). When the character changed, they became stimulants (S).

MD indicates how many data were missing for the variable. The SD column indicates whether the factor was a stimulant (S) or a de-stimulant (D). 
Table 2.

Cities in the ranking

\begin{tabular}{|c|c|c|}
\hline CAPITAL & MD & POPULATION \\
\hline Vienna & 3 & $1,766,746$ \\
\hline Brussels & 0 & $1,205,492$ \\
\hline Sofia & 0 & $1,238,438$ \\
\hline Prague & 2 & $1,324,277$ \\
\hline Berlin & 0 & $3,613,495$ \\
\hline Copenhagen & 1 & 559,440 \\
\hline Tallinn & 0 & 430,805 \\
\hline Athens & 2 & 664,046 \\
\hline Madrid & 1 & $3,223,334$ \\
\hline Paris & 0 & $9,803,494$ \\
\hline Helsinki & 0 & 643,272 \\
\hline Budapest & 1 & $1,749,734$ \\
\hline Dublin & 2 & 516,255 \\
\hline Rome & 1 & $2,872,800$ \\
\hline London & 3 & $8,866,541$ \\
\hline Vilnius & 0 & 547,484 \\
\hline Luxembourg & 2 & 115,227 \\
\hline Riga & 0 & 632,479 \\
\hline Amsterdam & 0 & 960,402 \\
\hline Oslo & 1 & 623,966 \\
\hline Warsaw & 2 & $1,735,442$ \\
\hline Lisbon & 1 & 507,220 \\
\hline Bucharest & 4 & $2,131,034$ \\
\hline Stockholm & 0 & 949,761 \\
\hline Ljubljana & 0 & 288,919 \\
\hline Bratislava & 1 & 432,864 \\
\hline Zagreb & 3 & 804,049 \\
\hline
\end{tabular}

Fundamental statistical indicators for the transformed variables were examined.

Table 3.

Statistical parameters of indicators after standardisation

\begin{tabular}{|c|c|c|c|c|c|c|c|}
\hline INDIC & Range & IQR & Quartile 1 & Quartile 2 & Quartile 3 & Skewness & Kurtosis \\
\hline V1 & 3.46 & 1.57 & -0.85 & 0.08 & 0.72 & -0.20 & -0.97 \\
\hline V2 & 3.94 & 1.20 & -0.62 & -0.14 & 0.58 & 0.39 & 0.02 \\
\hline V3 & 3.93 & 1.33 & -0.67 & 0.18 & 0.66 & -0.61 & -0.12 \\
\hline V4 & 3.72 & 1.33 & -0.58 & 0.26 & 0.76 & -0.79 & -0.32 \\
\hline V5 & 4.11 & 1.39 & -0.76 & -0.08 & 0.63 & 0.70 & 0.42 \\
\hline V6 & 3.95 & 1.31 & -0.71 & 0.22 & 0.60 & -0.49 & -0.17 \\
\hline V7 & 3.79 & 0.86 & -0.29 & 0.12 & 0.57 & -0.94 & 0.82 \\
\hline V8 & 3.96 & 1.07 & -0.31 & 0.25 & 0.77 & -1.64 & 2.65 \\
\hline V9 & 4.02 & 1.62 & -0.86 & 0.19 & 0.76 & -0.18 & -0.66 \\
\hline V10 & 3.49 & 1.36 & -0.63 & 0.09 & 0.73 & -0.05 & -0.88 \\
\hline V11 & 3.58 & 0.88 & -0.67 & -0.40 & 0.20 & 1.66 & 1.90 \\
\hline V12 & 3.56 & 0.99 & -0.35 & -0.06 & 0.64 & -0.33 & -0.34 \\
\hline V13 & 4.14 & 1.07 & -0.36 & 0.09 & 0.71 & -0.33 & 0.23 \\
\hline V14 & 4.53 & 1.25 & -0.46 & -0.07 & 0.79 & -0.60 & 0.90 \\
\hline V15 & 3.18 & 1.81 & -1.02 & 0.08 & 0.79 & 0.00 & -1.30 \\
\hline V16 & 4.90 & 1.06 & -0.42 & 0.14 & 0.64 & -1.94 & 6.48 \\
\hline V17 & 4.57 & 0.42 & 0.08 & 0.38 & 0.49 & -3.02 & 10.16 \\
\hline V18 & 2.45 & 2.11 & -1.33 & 0.42 & 0.78 & -0.51 & -1.58 \\
\hline
\end{tabular}


Cont. table 3.

\begin{tabular}{|c|c|c|c|c|c|c|c|}
\hline V19 & 3.09 & 1.81 & -0.90 & -0.02 & 0.91 & -0.16 & -1.36 \\
\hline V20 & 3.57 & 1.40 & -0.57 & 0.07 & 0.83 & -0.71 & -0.02 \\
\hline V21 & 3.23 & 1.28 & -0.43 & -0.08 & 0.85 & -0.60 & -0.45 \\
\hline V22 & 3.42 & 1.10 & -0.72 & -0.08 & 0.38 & 0.64 & -0.28 \\
\hline V23 & 4.07 & 1.69 & -1.10 & 0.06 & 0.59 & 0.81 & 1.30 \\
\hline V24 & 3.76 & 1.65 & -0.84 & 0.04 & 0.81 & 0.11 & -0.81 \\
\hline V25 & 4.99 & 0.85 & -0.32 & 0.14 & 0.53 & -0.91 & 2.27 \\
\hline
\end{tabular}

The values of the statistical parameters indicate the differentiation between variables. No variable could unambiguously distort the results of the ranking. Variables can be considered as appropriately selected.

\subsection{Methods}

Let us assume that we want to evaluate $m$ objects that are described by $n$ variables. In this case, we analyse the cities described by indicators.

\section{Hellwig linear ordering method}

The Hellwig method has the concept of a pattern (Hellwig 1968, 1981). The pattern is also called a reference point.

It is assumed that the variables are stimulants. Higher variable values indicate the desired higher level of the phenomenon. If a variable is not a stimulant, the value of the variable is multiplied by -1 .

Designation procedure

Stage 1 - standardisation. Very often variables are expressed in different units and have different order of magnitude, so variables are standardised. As a result of standardisation, variables have the following properties. The mean is zero, the standard deviation is one. The value range usually varies from -3 to 3 . The variable is standardised according to the formula:

$$
z_{i j}=\frac{x_{i j}-\bar{x}_{j}}{s_{j}}
$$

where:

$x_{i j}$ - observation of the $\mathrm{j}$-th indicator, for the 1 st object,

$\bar{x}_{j}-$ the average value for $\mathrm{j}$-th indicator,

$s_{j}-$ standard deviation value for $\mathrm{j}$-th indicator.

Stage 2 - specification of the coordinates of the standard. After you standardise variables, you can specify the coordinates of the pattern. All indicators are stimulants. The formula founds the value of the pattern:

$$
z_{0 j}=\max \left\{z_{i j}\right\}
$$


Step 3 - determining the distance from the pattern. Euclidean distance is used to determine the distance of objects from the pattern.

$$
d_{0 i}=\sqrt{\sum_{j}\left(z_{0 j}-z_{i j}\right)^{2}}
$$

Stage 4 - determining the value of an aggregate variable. To determine the value of an aggregate variable one needs to determine: the average distance from the standard (3), the standard deviation of the distance from the standard (4).

$$
\begin{aligned}
& \bar{d}_{0}=\sum_{j} d_{0 i} \\
& s_{0}=\sqrt{\frac{1}{n} \sum_{i}\left(\bar{d}_{0}-d_{0 i}\right)^{2}}
\end{aligned}
$$

Based on the average and the deviation of the standard distance from the standard we determine the critical distance of the pattern according to the formula:

$$
d_{0}=\bar{d}_{0}+2 s_{0}
$$

After determining a critical distance, we can calculate the value of the aggregate variable according to the formula.

$$
q_{\mathrm{i}}=1-\frac{d_{0 i}}{d_{0}}
$$

Based on the aggregate value one can designate the best object $-\max \left\{q_{\mathrm{i}}\right\}$, and the worst object $-\min \left\{q_{\mathrm{i}}\right\}$.

\section{TOPSIS method}

The TOPSIS method is an extension of the Hellwig method (Hwang et al., 1918). This method uses two reference points. The first is a pattern that is analogous to the Hellwig pattern. The second is an anti-pattern.

Step 1 - designation of pattern and anti-pattern

$$
\begin{aligned}
& z_{0 j}^{+}=\max \left\{z_{i j}\right\} \\
& z_{0 j}^{-}=\min \left\{z_{i j}\right\}
\end{aligned}
$$

Step 2 - determining the distance from patterns. Similarly, as in the Hellwig method, distances from each pattern are determined on the basis of formulas:

$$
\begin{aligned}
& d_{0 i}^{+}=\sqrt{\sum_{j}\left(z_{0 j}^{+}-z_{i j}\right)^{2}} \\
& d_{0 i}^{-}=\sqrt{\sum_{j}\left(z_{0 j}^{-}-z_{i j}\right)^{2}}
\end{aligned}
$$


Step 3 - determining the value of the aggregate variable. To determine the value of the variable, it is necessary to know the distance value (10), (11).

$$
q_{\mathrm{i}}=\frac{d_{0 i}^{-}}{d_{0 i}^{-}+d_{0 i}^{+}}
$$

\section{Smart City Index}

The larger the aggregate variable values, the better the object.

$$
\mathrm{SCI}=\frac{\sum O I_{i} w_{i}}{\sum w_{i}}
$$

for the area

$$
O I_{i}=\frac{\sum I_{i j} v_{i j}}{\sum v_{i j}}
$$

where:

$I_{i j}$ - value of the $\mathrm{j}$-th variable, a measure included in the $\mathrm{i}$-th area,

$v_{i j}$ - weight of the $\mathrm{j}$-th variable, the measure included in the $\mathrm{i}$-th area $\sum_{j} v_{i j}=1$,

$O I_{i}$ - index value for the i-th area,

$w_{i}$ - the weight of the $\mathrm{i}$-th area $\sum_{i} w_{i}=1$,

all weights are non-negative.

The indicator includes the following relationships between areas and their measures. It was considered that for determining the SCI value each area would have the same weight. The SCI value is the arithmetic mean of the indexes from the areas.

\section{Results and discussion}

According to the methodology presented, the following ranking of cities was obtained.

\begin{tabular}{|c|c|c|c|c|c|c|c|c|}
\hline & \multicolumn{3}{|c|}{ RANKING R: } & \multicolumn{3}{|c|}{ VALUE V: } & \multirow{2}{*}{$\begin{array}{c}\text { SCI VS } \\
\text { HELLWIG }\end{array}$} & \multirow{2}{*}{$\begin{array}{c}\text { SCI VS } \\
\text { TOPSIS }\end{array}$} \\
\hline CAPITAL & SCI & HELWIG & TOPSIS & SCI & HELWIG & TOPSIS & & \\
\hline Helsinki & 1 & 1 & 1 & 0.46 & 0.38 & 0.63 & 0 & 0 \\
\hline Oslo & 2 & 2 & 2 & 0.45 & 0.38 & 0.63 & 0 & 0 \\
\hline Tallinn & 3 & 4 & 3 & 0.42 & 0.37 & 0.62 & -1 & 0 \\
\hline Stockholm & 4 & 7 & 5 & 0.36 & 0.32 & 0.60 & -3 & -1 \\
\hline Vilnius & 5 & 3 & 4 & 0.36 & 0.37 & 0.61 & 2 & 1 \\
\hline Amsterdam & 6 & 5 & 7 & 0.32 & 0.34 & 0.60 & 1 & -1 \\
\hline Prague & 7 & 6 & 6 & 0.30 & 0.33 & 0.60 & 1 & 1 \\
\hline
\end{tabular}

Table 4.

Ranking results with comparison 
Cont. table 4.

\begin{tabular}{|c|c|c|c|c|c|c|c|c|}
\hline Copenhagen & 8 & 10 & 8 & 0.22 & 0.27 & 0.57 & -2 & 0 \\
\hline Luxembourg & 9 & 12 & 9 & 0.21 & 0.26 & 0.57 & -3 & 0 \\
\hline London & 10 & 9 & 10 & 0.12 & 0.27 & 0.57 & 1 & 0 \\
\hline Paris & 11 & 8 & 11 & 0.10 & 0.30 & 0.56 & 3 & 0 \\
\hline Vienna & 12 & 18 & 12 & 0.08 & 0.23 & 0.55 & -6 & 0 \\
\hline Ljubljana & 13 & 17 & 14 & 0.06 & 0.23 & 0.54 & -4 & -1 \\
\hline Dublin & 14 & 16 & 13 & 0.04 & 0.23 & 0.55 & -2 & 1 \\
\hline Berlin & 15 & 14 & 16 & -0.03 & 0.25 & 0.54 & 1 & -1 \\
\hline Riga & 16 & 11 & 15 & -0.03 & 0.26 & 0.54 & 5 & 1 \\
\hline Budapest & 17 & 15 & 17 & -0.07 & 0.24 & 0.53 & 2 & 0 \\
\hline Brussels & 18 & 13 & 19 & -0.07 & 0.26 & 0.52 & 5 & -1 \\
\hline Bratislava & 19 & 19 & 18 & -0.09 & 0.22 & 0.52 & 0 & 1 \\
\hline Sofia & 20 & 22 & 21 & -0.10 & 0.18 & 0.52 & -2 & -1 \\
\hline Warsaw & 21 & 20 & 20 & -0.13 & 0.22 & 0.52 & 1 & 1 \\
\hline Lisbon & 22 & 21 & 22 & -0.19 & 0.20 & 0.51 & 1 & 0 \\
\hline Madrid & 23 & 23 & 23 & -0.20 & 0.17 & 0.50 & 0 & 0 \\
\hline Zagreb & 24 & 24 & 24 & -0.26 & 0.17 & 0.49 & 0 & 0 \\
\hline Rome & 25 & 25 & 25 & -0.66 & -0.02 & 0.41 & 0 & 0 \\
\hline Athens & 26 & 26 & 26 & -0.79 & -0.05 & 0.40 & 0 & 0 \\
\hline Bucharest & 27 & 27 & 27 & -0.88 & -0.06 & 0.37 & 0 & 0 \\
\hline
\end{tabular}

In the light of the variables presented, Helsinki turned out to be the best city. Scandinavian capitals rank high. Smaller capitals also occupy high places. By comparing the results obtained, it can be concluded that the results obtained by TOPSIS are the closest to the SCI results.

Pearson's determined linear correlation coefficients indicate a strong linear relationship with the results obtained.

Table 5.

Pearson's determined linear correlation coefficients

\begin{tabular}{|l|r|r|r|r|r|r|}
\hline & \multicolumn{1}{|c|}{ SCI:R } & HELLWIG:R & TOPSIS:R & SCI:V & HELLWIG:V & TOPSIS:V \\
\hline SCI:R & 1.00 & & & & & \\
\hline HELLWIG:R & 0.95 & 1.00 & & & & \\
\hline TOPSIS:R & 1.00 & 0.95 & 1.00 & & & \\
\hline SCI:V & -0.93 & -0.90 & -0.93 & 1.00 & & \\
\hline HELLWIG:V & -0.88 & -0.90 & -0.88 & 0.98 & 1.00 & \\
\hline TOPSIS:V & -0.93 & -0.91 & -0.93 & 1.00 & 0.98 & 1.00 \\
\hline
\end{tabular}

The table compares the results of the rankings and the meters based on which they were created. Strong linear correlation relationships can be noticed. Therefore, these measures can be used interchangeably. When comparing the rankings with rankings using SCI, we see that the most significant change is present with the Hellwig method. It takes into account only the distance from the positive pattern. The TOPSIS method changes apply to at most one position. 


\section{Conclusion}

The measure of Hellwig's economic development as well as TOPSIS can be successfully used as linear ordering measures in the context of Smart City. Their advantage over SCI is that they can not only rank but also assess the distance. In the future it will be possible to try to construct a meter based on one of these two measures showing not only the ranking position. The advantage of these measures is that they take values in the range $[0,1]$.

\section{References}

1. Ahvenniemi, H., Huovila, A., Pinto-Seppä, I., Airaksinen, M. (2017). What are the differences between sustainable and smart cities? Cities, 60, pp. 234-245.

2. Albino, V., Berardi, U., Dangelico, R.M. (2015). Smart cities: Definitions, dimensions, performance, and initiatives. Journal of Urban Technology, 22(1), pp. 3-21.

3. Berrone, P., Ricart, J.E., Duch, A., Carrasco, C. (2019). IESE Cities in Motion Index 2019, IESE, ST-509-E, 05/2019 DOI: https://dx.doi.org/10.15581/018.ST-509.

4. Bosch, P., Jongeneel, S., Neumann, H.-M., Branislav, I., Huovila, A., Airaksinen, M., PintoSeppä, I. (2017a). Recommendations for a Smart City index. CITYkeys - Smart city performance measurement framework. DOI: 10.13140/RG.2.2.20190.74562, 16.04.2020.

5. Bosch, P., Jongeneel, S., Rovers, V., Neumann, H.-M., Airaksinen, M., Huovila, A. (2017b). CITYkeys indicators for smart city projects and smart cities. CITYkeys - Smart city performance measurement framework. DOI: 10.13140/RG.2.2.17148.23686, 16.04.2020.

6. Giffinger, R., Fertner, C., Kramar, H., Kramar, H., Kalasek, R., Pichler-Milanovic, N., Meijers, E. (2007). Smart Cities. Ranking of European medium-sized cities. Centre for Regional Science, Vienna University of Technology, http://www.smart-cities.eu/download/ smart_cities_final_report.pdf, 16.04.2020.

7. Hellwig, Z. (1981). Wielowymiarowa analiza porównawcza i jej zastosowanie w badaniach wielocechowych obiektów gospodarczych. In: Metody $i$ modele ekonomicznomatematyczne $w$ doskonaleniu zarządzania gospodarka socjalistyczna. Warszawa: PWE.

8. Hellwig, Z. (1968). Zastosowanie metody taksonomicznej do typologicznego podziału krajów ze względu na poziom ich rozwoju oraz zasobu i strukturę wykwalifikowanych kadr. Przegląd Statystyczny, z. 4, 307-327.

9. Huovila, A., Penttinen, T., Airaksinen, M., Pinto-Seppä, I., Piira, K., Penttinen, T. (2016, September). Smart city performance measurement system. Proceedings of the 41 st IAHS World Congress Sustainability Innovation for the Future, Algarve, Portugal, pp. 13-16. 
10. Hwang, C.L., Yoon, K. (1981). Mutliple Attribute Decision Making: Methods and Application. New York: Springer-Verlag.

11. Kukuła, K. (1989). Statistical structural analysis and its application in the field of production services for agriculture. Scientific Notebooks AE in Krakow, Special series: Monographs, 89, p. 256.

12. Kukuła, K. (2000). Method of zeroed unitarisation. Warsaw: PWN.

13. Lombardi, P., Giordano, S., Caragliu, A., Del Bo, C., Deakin, M., Nijkamp, P., Kourtit, K. (2011). An advanced triple-helix network model for smart cities performance. Vrije Universiteit Amsterdam, Research Memorandum 2011-45, http://degree.ubvu.vu.nl/ repec/vua/wpaper/pdf/20110045.pdf, 15.03.2019.

14. Smart City PROFILES (2013). Ergebnisse. 7.6.2013. http://www.smartcities.at/assets/03Begleitmassnahmen/SmartCity-PDF-INTRO.pdf, 16.03.2020.

15. Sojda, A., Owczarek, T., Wolny, M. (2018). Smart city in data-oriented terms - Poland in eurostat - database. Zeszyty Naukowe PŚl., Org. Zarz., z. 130, p. 557-566, DOI: 10.29119/1641-3466.2018.130.46.

16. Sojda, A., Wolny, M. (2020). The impact of standardisation method on smart city ranking, Sil. Univ. Technol. Sci. Pap., Organ. Manage., no. 142, pp. 83-94, DOI: 10.29119/16413466.2020.142.6.

17. Stankovic, J., Dzunic, M., Džunić, Ž., Marinkovic, S. (2015). A multi-criteria evaluation of the European cities' smart performance: Economic, social and environmental aspects. Zbornik radova Ekonomskog fakulteta u Rijeci, časopis za ekonomsku teoriju i praksuProceedings of Rijeka Faculty of Economics, Journal of Economics and Business, 35(2), pp. 519-550.

18. Svítek, M., Skobelev, P., Kozhevnikov (2020). Smart City 5.0 as an Urban Ecosystem of Smart Services. 10.1007/978-3-030-27477-1_33.

19. Szczech-Pietkiewicz, E. (2015). Smart city - sample definition and measurement. Scientific work of the University of Economics in Wroclaw. Local economy in theory and practice, 391.

20. Tahir, Z., Malek, J.A. (2016). Main criteria in the development of smart cities determined using analytical method. Planning Malaysia Journal, 14(5).

21. UCLG (2012). Smart Cities Study: International study on the situation of ICT, innovation and knowledge in cities. Bilbao. http://www.uclg-digitalcities.org/app/uploads/2015/06 /en_smartcitiesstudy.pdf, 16.04.2020.

22. United Nations (2014). World urbanisation prospects: The 2014 Revision, Highlights (ST/ESA/SER.A/352). New York. United States of America, https://doi.org/10.4054/ DemRes.2005.12.9. 